\title{
The Impact of Immigration on Labor Cost in EU: Is There a Threshold Effect?
}

\author{
Atakan DURMAZ - Ömer AKKUŞ*
}

\begin{abstract}
In this study, the impacts of migration on labor costs are examined within the framework of structural approach by using nonlinear components of migration and labor cost 22 European Union member countries for the period $2000-2017$. While labor cost is determined as dependent variable, the ratio of immigration to country population is determined as regime dependent regressor and threshold variable and panel threshold method is used in the study. The findings indicate that there is a single threshold level for the established model. In the first regime below the threshold value, it is determined that an increase in immigration reduces labor costs, and if the immigration exceeds the threshold value, it is concluded that the immigration has no effect on the labor costs.
\end{abstract}

Keywords: labor cost, immigration, threshold effect, labor market, emigration

JEL Classification: F22, C24, J30

DOI: https://doi.org/10.31577/ekoncas.2021.08.02

\section{Introduction}

In this day and age, more than $3 \%$ of the world's population lives outside the homeland. Although it depends on the factors triggering migration, it has been shown in the researches that the majority of this activity is directed towards high income countries. ${ }^{1}$ When the distribution of migration flows across the world is analyzed, it is observed that the migration trend towards developed countries gained momentum (from $7.2 \%$ in 1990 to $11.2 \%$ in 2015), although the migration

\footnotetext{
* Atakan DURMAZ, corresponding author - Ömer AKKUŞ, University of Samsun, Faculty of Economics Administrative and Social Sciences, Department of Economics and Finance, 55080 Samsun, Turkey; e-mail: atakan.durmaz@ samsun.edu.tr; omer.akkus@ samsun.edu.tr

${ }^{1}$ According to UN 2017 data, approximately 258 million people live outside their homeland. Out of these, $64 \%$ (165 million people) live in high income countries, while $36 \%$ live in middle and low income countries.
} 
tendency towards developing countries was stable at $1.7 \%$ levels in the last 10 years (Edo, 2019).

Although migration flows have been examined in different aspects in the economic literature, one of the most focused issues is the effects of these flows on the labor market of both the immigrant and emigrant countries. In particular, the effects of immigrants on wages and labor force participation rates in the country of immigration are discussed extensively in the relevant literature. According to standard economic models, migration affects the labor market through labor supply. The increase in labor supply adversely affects labor productivity and reduces the level of physical capital per labor force. This reduces the average wages of the local labor force (Borjas, 2013; Glitz, 2014). In the long run, the decrease in wages and the increase in employment are expected to increase capital accumulation (Friedberg and Hunt, 1995). The increase in capital stock increases labor productivity and labor demand, thereby reducing the first harmful wage effects created by the labor supply shock. Therefore, preliminary studies on the issue have concluded that the impact of migration flows on domestic wages and/or labor force participation rates is insignificant (Card, 1990; Friedberg and Hunt, 1995). However, some of the recent studies have shown that migration flows have positive effects on the local labor market, while some have concluded that they do not have any effects on it. There are even studies that have negative effects (Borjas, 2003; Dustmann, Schönberg and Stuhler, 2016; Edo, 2019). It can be said that there are three main reasons why such disparate results come out and some of the results are seen as contrary to the law of supply and demand (Edo and Rapoport, 2019). The first of these reasons is that there is no substitution relationship between migrants and local labor due to factors such as differences in educational level or lack of complementary educational characteristics between migrants and local labor force (Peri and Sparber, 2009; Dustmann, Frattini and Preston, 2013; Durmaz and Kalça, 2018). Second, the wage stickiness of the receiving country, the effectiveness of trade unions or other institutional characteristics may hinder the regulatory effects of migration flows on the labor market (Angrist and Kugler, 2003; Glitz, 2012; Edo, 2016). The third and last reason is that the local labor force reacts internally to migration flows, which are an external shock. In some immigrant countries, local labor may gain different capabilities in response to migration flows or to maintain their position in the current labor market (Hunt, 2017). In some cases, local labor can move to other regions or sectors within the country in response to migration flows (Borjas, 2003; Monras, 2015; Cadena and Kovak, 2016; Piyapromdee, 2017).

In this study, the effects of migration flows (inflows and outflows) on the local labor market are examined from a different point of view. In this respect, 
the effect of migration on the local labor market by means of nonlinear components of migration and labor costs was investigated within the framework of the threshold value approach by using various control variables. The study consists of four sections. In the second section following the introductory section, the literature research on the subject takes place, in the third section, the data set and method used in the research are explained and the findings are discussed. The fourth and final section consists of the conclusion and evaluation section.

\section{Literature Reviews}

When the studies on the effects of migration flows on local labor markets are evaluated in general, it is observed that empirical studies are grouped into two groups as structural studies that try to explain the relationship between wages and/or employment and migration flows through simulations on theoretical background and non-structural studies that examine the relationship between labor markets and migration flows on the basis of geographical clusters and skill groups. Although they have important features in both approaches, non-structural studies reveal more data-based results than others. Table 1 summarizes the advantages and disadvantages of these two main approaches and sub-approaches.

T a ble 1

Basic Approaches to Measure the Effects of Migration Flows on Labor Markets

\begin{tabular}{|l|l|l|l|}
\hline \multicolumn{5}{|c|}{ Empirical strategy } & \multicolumn{1}{c|}{ Advantages } & \multicolumn{2}{c|}{ Disadvantages } \\
\hline \multicolumn{5}{|c|}{} & $\begin{array}{l}\text { It attempts to simulate the effects } \\
\text { of migration on the labor market } \\
\text { through a theoretical framework } \\
\text { through changes in wages } \\
\text { or employment. }\end{array}$ & $\begin{array}{l}\text { Modeling and seizing } \\
\text { the total labor market } \\
\text { impacts resulting from } \\
\text { migration }\end{array}$ & $\begin{array}{l}\text { Simulation results are } \\
\text { theoretical and sensitive } \\
\text { to changes in the basic } \\
\text { theoretical framework }\end{array}$ \\
\hline $\begin{array}{l}\text { Spatial } \\
\text { correlation } \\
\text { approach }\end{array}$ & $\begin{array}{l}\text { Compares changes in wage or } \\
\text { employment levels in areas with } \\
\text { high and low migrant popula- } \\
\text { tions. }\end{array}$ & $\begin{array}{l}\text { Captures the total } \\
\text { labor market effects } \\
\text { of migration at local } \\
\text { level. }\end{array}$ & $\begin{array}{l}\text { Endogenous locations of } \\
\text { migrants and cross-border } \\
\text { regulations }\end{array}$ \\
\hline $\begin{array}{l}\text { National } \\
\text { skill cell } \\
\text { approach }\end{array}$ & $\begin{array}{l}\text { Compares changes in wage } \\
\text { or employment levels for high } \\
\text { and low immigrant populations } \\
\text { and defined skill groups in terms } \\
\text { of education and experience and/ } \\
\text { or occupation. }\end{array}$ & $\begin{array}{l}\text { Neutralizes } \\
\text { cross-domain settings. }\end{array}$ & $\begin{array}{l}\text { It measures the partial } \\
\text { impact of migrant entry in } \\
\text { a particular skill group on } \\
\text { the wages or employment } \\
\text { of domestic workers from } \\
\text { that group. }\end{array}$ \\
\hline $\begin{array}{l}\text { Natural } \\
\text { experiment }\end{array}$ & $\begin{array}{l}\text { Compares the impact of } \\
\text { the intensity of sudden, large, } \\
\text { and unexpected migration flows } \\
\text { in the field and/or skill groups on } \\
\text { changes in wage or employment } \\
\text { levels. }\end{array}$ & $\begin{array}{l}\text { Reduces prejudice } \\
\text { caused by endogenous } \\
\text { penetration of migrants } \\
\text { between field and skill } \\
\text { groups. }\end{array}$ & $\begin{array}{l}\text { It is inadequate to represent } \\
\text { typical models of migration } \\
\text { to high-income countries. }\end{array}$ \\
\hline
\end{tabular}

Source: Edo (2019, p. 928). 
Considering the scope of the study and the data set, this study takes shape within the framework of the structural approach due to the consideration of the effectiveness of the theoretical foundations, although both structural and nonstructural approaches contain features with both features. Therefore, rather than all the structural and non-structural studies in the related literature, the studies within the framework of structural approach are examined in a more comprehensive manner. The studies conducted in this context are aimed at examining the effects of immigrants on the wages of the local labor force from the data sets related to different countries and groups of countries. Some of the structural approaches, such as Babecký et al. (2010), based on classical labor market analysis, have attempted to broaden the approach through wage rigidity in countries. Accordingly, institutional factors such as minimum wage, unemployment allowance and strong union structures can absorb the possible effects of migrationinduced labor supply shocks on wages. According to the common result of studies such as Aydemir and Borjas (2007), D'Amuri, Ottaviano and Peri (2010), Gerfin and Kayser (2010), Ottaviano and Peri (2012), Brücker, Hauptmann and Upward (2014) and Edo and Toubal (2015), the impact of immigration on the wages in the local labor market varies according to the degree of substitution of the migrant labor force and the local labor force in the long-run period, where capital flows fully adapt to migration-induced labor supply shocks. Accordingly, the impact of immigrant supply shocks on the wages of the local labor force in the long run is either positive or negligible, since the immigrant labor force and the local labor force have very low chances of having full substitution even if they have similar education and experience. Ottaviano and Peri (2012), Manacorda, Manning and Wadsworth (2012), D'Amuri, Ottaviano and Peri (2010) and Brïcker, Hauptmann and Upward (2014) concluded that there is an incomplete substitution relationship between immigrants and the local labor force. Ottaviano and Peri (2012) found that immigrants increased local wages by $0.6 \%$ in the long term in the study examining the US economy for the period of $1990-2006$.

They also concluded that, contrary to the local labor force, new immigrants entered the competition process with migrants migrating in previous periods and reduced their average wages. In contrast, Borjas (2014) and Edo and Toubal (2015) concluded that immigrants and local labor force (with a similar level of education and experience) can fully substitute each other and do not affect the average wages of immigrants in the long run.

Another factor that determines the effect of immigrants on the local labor market is the skills of immigrants. In the long run, there are studies showing that immigrants increase the labor supply of some groups and cause changes in their average wage structures. 
Especially in some developed countries, the fact that immigrant groups consist of high skilled labor force increased the number of high skilled labor force and contributed to the reduction of wage inequality between the local high skilled and the local low skilled labor force. This situation also contributes positively to income inequality between skilled labor force and unskilled labor force in the country. In his study, Edo (2019) stated that immigrants reduced the average wages of the highly skilled labor force in the country by about $1 \%$, whereas the low skilled labor force increased the average wages by $0.5 \%$. Similarly, Docquier, Ozden and Peri (2014), in their study for OECD countries, found that immigrants coming to OECD countries between 1990 and 2000 had a positive effect on the average wages and employment of low skilled local labor force. In some countries such as Denmark and Sweden, the fact that immigrants are low skilled than the local labor force caused more income inequality between the skilled labor force and the unskilled labor force. Consequently, structural studies reveal that the impact of migration on wages in the local labor market depends on the nature of the migrant labor force and the structure of the labor market of the receiving country.

When the studies on the effects of migration flows on the labor markets of the homeland, it is seen that various methodologies, datasets and country/country groups are included in the research. While most of the related studies focus on the effects of emigration on average wages in local labor markets, there are few studies examining the effect of emigration on unemployment rates in the homeland (Barrell, Fitzgerald and Riley, 2010; Hazans and Philips, 2011; Pryymachenko, Fregert and Andersson, 2013; Zaiceva, 2014; Škuflić and Vučković, 2018). However, the results obtained differ. In his study on Poland, Kaczmarczyk (2012) concluded that emigration had no effect on employment level in short-run and average wages in long-run. Dustmann, Frattini and Rosso (2015) in his study for the same country, data from $1998-2007$ period were used. According to the results, the effect of the emigration process on the labor market differs according to skill groups. Accordingly, the most emigration movement in this process is in the labor force with medium skill. This increases the average wages of the intermediate skilled labor force in the country, while causing a low reduction in the wages of the unskilled labor force. Elsner (2013), in his study on Lithuania, concluded that emigration had no effect on the wages of older workers, but increased the wages of young workers by about $6 \%$ for 5 years. In addition, it is stated in the study that emigration has no effect on wage distribution between high skilled labor and low skilled labor.

When the literature is analyzed in general, it can be seen that studies on both immigration and emigration evaluate the effects of migration flows on the labor 
market with a single result. The most important contribution of this study to the literature is that it tries to create a multiple focus by investigating whether the effect of migration flows on labor costs occurs around certain threshold values.

\section{Empirical Methods}

\subsection{Descriptive Statistics}

The study aims to reveal the impact of migration flows on labor costs by using non-linear components of migration and labor costs by using various control variables. Annual data of $2000-2017$ belonging to 22 countries $^{2}$ included in the EU are used in the study. The main reason behind not being able to use all the countries included in the EU is the lack of data from countries excluded from the analysis and the sensitivity of the panel threshold method used to balanced panel data. Some basic descriptive statistics of the data set used in the study are presented in Table 2.

T a b l e 2

\section{Descriptive Statistics}

\begin{tabular}{|l|c|c|c|c|c|}
\hline Variable & Obs & Mean & Std. Dev. & Min & Max \\
\hline Laborcost & 396 & 94.9543 & 12.2054 & 54.2 & 130.6 \\
Unemployment & 396 & 9.0871 & 4.4143 & 2.9 & 27.5 \\
Immigration & 396 & 0.7134 & 0.4882 & 0.0025 & 3.2627 \\
Emigration & 396 & 0.5517 & 0.4032 & 0 & 2.6848 \\
Import & 396 & 50.66 & 19.136 & 22.908 & 104.63 \\
Export & 396 & 51.921 & 21.969 & 18.545 & 122.14 \\
Total factor productivity & 396 & 0.9625 & 0.0783 & 0.686 & 1.236 \\
\hline
\end{tabular}

Note : laborcost $=$ the total cost on an hourly basis of employing labour. All statistics are based on a harmonised definition of labour costs, unemployment $=$ unemployment rate, immigration $=$ the ratio of total immigration to the country population throughout the year, emigration $=$ the ratio of total immigration from the country to the country population throughout the year import $=$ the share of the total value of the imported total goods and services in the gross domestic product, export $=$ the share of the total value of the exported total goods and services in the gross domestic product, total factor productivity $=$ measured as the ratio of aggregate output to aggregate inputs.

Source: Authors' estimations.

Table 2 shows the means, standard errors, minimum and maximum values of the variables. When the sample group is analyzed, it is seen that the labor costs index in the European Union countries in the period of 2000 - 2017 is 94.95 on average and unemployment is $9 \%$ on average and the ratio of immigration to population is approximately $0.71 \%$ and the ratio of emigration to population is

\footnotetext{
${ }^{2}$ Belgium, Czech Republic, Denmark, Germany, Estonia, Ireland, Greece, Spain, France, Italy, Latvia, Lithuania, Hungary, Netherlands, Austria, Poland, Portugal, Slovenia, Slovakia, Finland, Sweden, United Kingdom.
} 
approximately $0.55 \%$ and the total factor productivity index based on 2010 is approximately 0.96 .

The relationship between the average labor costs and the average immigration for the period is shown in Figure 1 of the scatter plot. The scatter diagram presents the relationship between labor costs and immigration to the country in the value range of the data set. This data graph undoubtedly does not control other factors than migration that can affect labor costs. Therefore, some control variables other than the migration variable are included in the model.

Figure 1

\section{Labor Cost and Immigration/Population Averages}

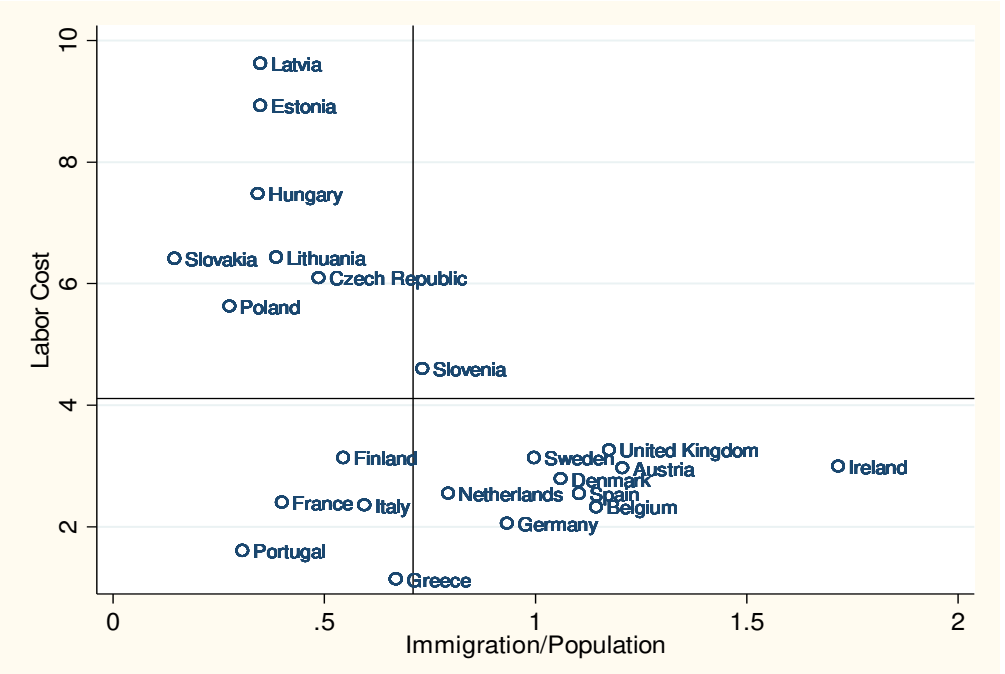

Note: While the average value of the change in labor costs in the 22 countries of the EU in the period of $2000-$ 2017 is $4.1 \%$ compared to the previous period, the average value of the rate of migration to the population is $0.71 \%$.

Source: Authors' estimations.

Figure 1 contains important information. Considering this information, Ireland is the country with the highest ratio of immigration to population in EU for the period of $2000-2017$. When the ratio of immigration to population is analyzed, it is seen that more developed countries in EU receive more immigration than the countries that joined the union later. On the other hand, considering the average value of the change in labor costs compared to the previous period, it can be said that this rate is higher in Latvia compared to other countries. One of the countries that draw attention in the figure is Slovenia. Slovenia not only immigrates above the average of the EU countries as a country immigration compared to its population, but also the average of the labor costs change compared to the previous period is above the average labor costs in the EU countries. 
Table 3 indicates the correlation matrix of the variables. When Table 3 is analyzed, it is seen that there is a negative relationship between immigration and labor costs.

T a b le 3

\section{Correlation of Variables}

\begin{tabular}{|l|c|c|c|c|c|c|c|}
\hline Variables & $\mathbf{1}$ & $\mathbf{2}$ & $\mathbf{3}$ & $\mathbf{4}$ & $\mathbf{5}$ & $\mathbf{6}$ & $\mathbf{7}$ \\
\hline 1 & 1.000 & & & & & & \\
2 & $-0.245^{*}$ & 1.000 & & & & & \\
3 & $-0.229^{*}$ & $-0.349^{*}$ & 1.000 & & & & \\
4 & $-0.177^{*}$ & $0.143^{*}$ & $0.344^{*}$ & 1.000 & & & \\
5 & $0.218^{*}$ & $-0.104^{*}$ & -0.005 & $0.263^{*}$ & 1.000 & & \\
6 & 0.075 & $-0.154^{*}$ & $0.118^{*}$ & $0.306^{*}$ & $0.962^{*}$ & 1.000 & \\
7 & $-0.246^{*}$ & $-0.211^{*}$ & $0.172^{*}$ & $-0.187^{*}$ & $-0.298^{*}$ & $-0.270^{*}$ & 1.000 \\
\hline
\end{tabular}

Note: Laborcost(1), unemployment(2), immigration(3), emigration(4), import(5), export(6), total factor productivity(7); * shows significance at the $5 \%$ level.

Source: Authors' estimations.

\subsection{Econometric Model}

Testing the cross-sectional dependency in panel data models is very important in terms of making appropriate predictions. When $\mathrm{T}>\mathrm{N}$, it is recommended to use the LM test developed by Breusch and Pagan (1980). However, when N > T, LM test statistics do not contain any desired statistical properties since significant dimensional distortions occur in the LM test statistics. This problem is solved by using Pesaran (2004) cross section dependency test (CD) (Hoyos and Sarafidis, 2006, p. 483). Pesaran (2004) proposes an alternative equation (1) format for balanced panel data models as follows:

$$
C D=\sqrt{\frac{2 T}{N(N-1)}}\left(\sum_{i=1}^{N-1} \sum_{j=i+1}^{N} \widehat{\rho_{i j}}\right)
$$

Here, if the $\mathrm{CD} \rightarrow \mathrm{N}(0,1)$ and $\mathrm{N} \rightarrow \infty$ and $\mathrm{T}$ are large enough, the $H_{0}$ hypothesis indicates that there is no cross-section dependency.

T a ble 4

Pesaran (2004) Cross Section Dependency Test Results

\begin{tabular}{|l|c|c|}
\hline Variables & Test statistics & Prob. \\
\hline Laborcost & 53.394 & 0.000 \\
Unemployment & 15.987 & 0.000 \\
İmmigration & 11.802 & 0.000 \\
Emigration & 18.711 & 0.000 \\
İmport & 48.494 & 0.000 \\
Export & 47.903 & 0.000 \\
Total factor productivity & 18.995 & 0.000 \\
\hline
\end{tabular}

Source: Authors' estimations. 
According to the results in Table 4, the hypothesis that $H_{0}$ has no cross section dependency is rejected and it is determined that there is a cross section dependency among the countries at 5\% significance level. Based on these results, it is concluded that a change in the situation of the immigrant or the emigration affects other EU countries. Cross section dependence results also influence the panel unit root tests to be applied.

For this reason, Im, Pesaran and Shin (2003) panel unit root test, which takes into account the cross section dependency, is used when performing panel unit root tests.

T a b le 5

Im, Pesaran Shin Panel Unit Root Test Results

\begin{tabular}{|c|c|c|c|c|c|}
\hline Level & \multicolumn{2}{|c|}{ Intercept } & & \multicolumn{2}{|c|}{ Trend and Intercept } \\
\hline Variables & Test statistic & p-value & Variables & Test statistic & p-value \\
\hline $\begin{array}{l}\text { Laborcost } \\
\text { Unemployment } \\
\text { İmmigration } \\
\text { Emigration } \\
\text { İmport } \\
\text { Export } \\
\text { Total factor } \\
\text { productivity }\end{array}$ & $\begin{array}{r}1.057 \\
1.272 \\
0.918 \\
0.995 \\
0.068 \\
1.849 \\
-0.630 \\
\end{array}$ & $\begin{array}{l}0.855 \\
0.898 \\
0.821 \\
0.840 \\
0.527 \\
0.968 \\
\\
\end{array}$ & $\begin{array}{l}\text { Laborcost } \\
\text { Unemployment } \\
\text { İmmigration } \\
\text { Emigration } \\
\text { İmport } \\
\text { Export } \\
\text { Total factor } \\
\text { productivity }\end{array}$ & $\begin{array}{r}0.365 \\
0.630 \\
-2.489 \\
-1.106 \\
-5.772 \\
-4.128 \\
-1.609 \\
\end{array}$ & $\begin{array}{l}\mathbf{0 . 6 4 3} \\
\mathbf{0 . 7 3 6} \\
0.006 \\
\mathbf{0 . 1 3 5} \\
0.000 \\
0.000 \\
\\
\\
\mathbf{0 . 0 5 4} \\
\end{array}$ \\
\hline $1^{\text {st }}$ Difference & \multicolumn{2}{|c|}{ Intercept } & & \multicolumn{2}{|c|}{ Trend and Intercept } \\
\hline Variables & Test statistic & Prob. & Variables & Test statistic & Prob. \\
\hline $\begin{array}{l}\text { Laborcost } \\
\text { Unemployment } \\
\text { İmmigration } \\
\text { Emigration } \\
\text { İmport } \\
\text { Export } \\
\text { Total factor } \\
\text { productivity }\end{array}$ & $\begin{array}{l}-5.758 \\
-4.347 \\
-7.928 \\
-7.911 \\
-8.218 \\
-8.116 \\
-6.926 \\
\end{array}$ & $\begin{array}{l}0.000 \\
0.000 \\
0.000 \\
0.000 \\
0.000 \\
0.000 \\
0.000 \\
\end{array}$ & $\begin{array}{l}\text { Laborcost } \\
\text { Unemployment } \\
\text { İmmigration } \\
\text { Emigration } \\
\text { İmport } \\
\text { Export } \\
\text { Total factor } \\
\text { productivity }\end{array}$ & $\begin{array}{l}-6.600 \\
-4.789 \\
-8.448 \\
-8.391 \\
-8.432 \\
-8.363 \\
-7.243 \\
\end{array}$ & $\begin{array}{l}0.000 \\
0.000 \\
0.000 \\
0.000 \\
0.000 \\
0.000 \\
\\
0.000 \\
\end{array}$ \\
\hline
\end{tabular}

Source: Authors' estimations.

Heterogeneity appears as a common problem of panel data. Each country in studies is different and structural relationships can vary from country to country. Fixed effect or random effect models reflect only heterogeneity in constants. Hsiao (2003) takes this problem into account and examines many variable slope models. Among these models, although the Hansen (1999) panel threshold model has a simple specification, it offers clear suggestions for economic policy implications. The use of Threshold Models is frequently encountered in time series analysis. Threshold models are used to indicate structural breaks or regime changes in the relationships between variables (Wang, 2015, p. 121). Tong (1983) TAR model is one of the most frequently used models in nonlinear time series models. 
The study of Hansen (1999) is based on the balanced panel dataset $\left(y_{i t}, q_{i t}, x_{i t}: 1 \leq i \leq n, 1 \leq t \leq T\right)$. As $i$ represents individual as subscript, $t$ represents time. $y_{i t}, q_{i t}$, regressor $x_{i t}$, I (.) used in the model represent the dependent variable, the threshold variable, a $\mathrm{k}$ vector and the indicator function respectively. The structural equation used can be illustrated as follows;

$$
y_{i t}=\mu_{i}+\beta_{1}{ }^{\prime} x_{i t} I\left(q_{i t} \leq \gamma\right)+\beta_{2}{ }^{\prime} x_{i t} I q_{i t}>\gamma+e_{i t}
$$

Alternative representation of equation 2 is;

$x_{i t}(\gamma)=x_{i t} I\left(q_{i t} \leq \gamma\right) x_{i t} I\left(q_{i t}>\gamma\right)$ and $\beta=\left(\beta_{1}^{\prime} \beta_{2}^{\prime}\right)$ so that the equation 2 equals

$$
y_{i t}=\mu_{i}+\beta^{\prime} x_{i t}(\gamma)+e_{i t}
$$

$\gamma$; shows the threshold parameter dividing the equation into two regimes with $\beta_{1}$ ve $\beta_{2}$ coefficients. In order to determine $\beta_{1}$ and $\beta_{2}$ the elements of $x_{i t}$ should not change over time. Hansen (1999) also assumes that the threshold variable $q_{i t}$ does not change over time.

Testing the threshold effect in the model is the same as testing whether the coefficients are the same in each regime.

$$
\begin{aligned}
& H_{0}: \beta_{1}=\beta_{2} \\
& H_{\alpha}: \beta_{1} \neq \beta_{2}
\end{aligned}
$$

While the $H_{0}$ hypothesis is that the model is linear, the alternative hypothesis is that the model is a single-threshold model. Critical values of F test are obtained with boostrap in order to test the significance of the threshold effect.

\subsection{Results and Discussion}

The relationship between migration and labor costs is investigated using the balanced panel data of 22 EU countries between 2000 - 2017. The control variables used in the study have been selected considering the empirical literature (Aydemir and Borjas, 2007; D'Amuri, Ottaviano and Peri, 2010; Gerfin and Kayser, 2010; Ottaviano and Peri, 2012; Brücker, Hauptmann and Upward, 2014 and Edo and Toubal, 2015).

$$
\begin{aligned}
& \text { laborcost } \left.=\mu_{i}+\beta_{1} \text { immigration }_{i t} \text { I }_{\text {immigration }} \leq \text { it } \leq \gamma\right)+ \\
& \left.+\beta_{2} \text { immigration }_{i t} \text { I }_{\text {immigration }}>\gamma\right)+e_{i t}
\end{aligned}
$$

While the dependent variable is labor costs in the model, the rate of migration to the population is determined as regime-dependent regressor and threshold variable. 
T a b le 6

Single Threshold Value Estimator

\begin{tabular}{|}
\begin{tabular}{|l|c|c|c|c|c|c|c|}
\hline \multicolumn{1}{|c|}{ Threshold estimator (level = 95) } \\
\hline \multicolumn{1}{|c|}{ Model } & Threshold & Lower & Upper & & \\
\hline \multicolumn{2}{|c|}{0.1912} & 0.1886 & 0.1954 & & Crit1 \\
\hline Threshold effect test (bootstrap = 10000) \\
\hline Threshold & RSS & MSE & Fstat & Prob & Crit10 & Crit & Crit \\
\hline Single & 2474.608 & 6.932 & 30.440 & 0.000 & 14.761 & 16.559 & 19.300 \\
\hline
\end{tabular}
\end{tabular}

Source: Authors' estimations.

T a b le 7

Two Threshold Estimators

\begin{tabular}{|c|c|c|c|c|c|c|c|}
\hline \multicolumn{8}{|c|}{ Threshold estimator $($ level = 95) } \\
\hline Model & Threshold & Lower & Upper & & & & \\
\hline$\gamma$ & 0.1912 & 0.1886 & 0.1954 & & & & \\
\hline Th-2 & 0.5513 & 0.5496 & 0.5513 & & & & \\
\hline \multicolumn{8}{|c|}{ Threshold effect test $($ bootstrap $=\mathbf{1 0 0 0 0}$ ) } \\
\hline Threshold & $R S S$ & $M S E$ & Fstat & Prob & Crit10 & Crit5 & Crit1 \\
\hline Single & 2474.608 & 6.932 & 30.440 & 0.000 & 14.761 & 16.559 & 19.300 \\
\hline Double & 2388.931 & 6.692 & 5.570 & 0.790 & 14.783 & 16.413 & 23.784 \\
\hline
\end{tabular}

Source: Authors' estimations.

Figure 2

First Threshold Graph

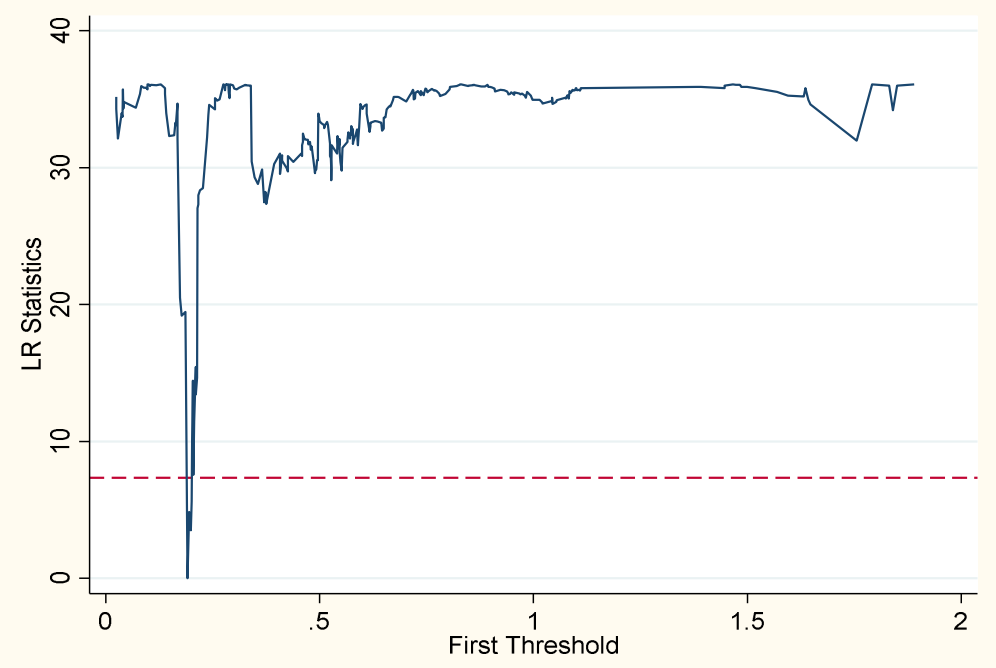

Source: Authors' estimations. 
The test results of the significance of the single-threshold model, which is an alternative hypothesis versus the linear model, are presented in Table 6. Table 7 contains the results of whether two threshold values exist for the single-threshold model. The results obtained prove the existence of a single threshold level for the established model. It is determined that there is a single threshold value $\gamma=0.19$ in the model. When the significance of this threshold value is examined and Fstat $=30.44>16,55$, it is found that the value of the immigration variable $0.19 \%$ indicates the presence of two different regimes. The LR statistics showing the first threshold value is presented in Figure 2.

With the determination of this threshold value, it is concluded that there are two different regimes in the model. Three different model predictions are made in the study. Model 1 and model 2 do not include emigration, but model 3 includes the effect of emigration.

Table 8

Model Results

\begin{tabular}{|c|c|c|c|}
\hline Variables & Model 1 & Model 2 & Model 3 \\
\hline \multicolumn{4}{|l|}{ Laborcost } \\
\hline Unemployment & $\begin{array}{l}-0.575 \text { *** } \\
(0.113)\end{array}$ & $\begin{array}{l}-0.598 * * * \\
(0.112)\end{array}$ & $\begin{array}{c}-0.564 * * * \\
(0.116)\end{array}$ \\
\hline İmport & $\begin{array}{l}0.163 * * \\
(0.075)\end{array}$ & $\begin{array}{r}0.139^{*} \\
(0.075) \\
\end{array}$ & $\begin{array}{l}0.161 * * \\
(0.076)\end{array}$ \\
\hline Export & $\begin{array}{c}-0.410 * * \\
(0.084)\end{array}$ & $\begin{array}{c}-0.395 * * * \\
(0.084)\end{array}$ & $\begin{array}{c}-0.407 * * * \\
(0.085)\end{array}$ \\
\hline Emigration & & & $\begin{array}{c}-0.345 \\
(0.979)\end{array}$ \\
\hline Total factor productivity & $\begin{array}{c}-53.807 * * * * \\
(7.795)\end{array}$ & $\begin{array}{c}-52.496 * * * \\
(7.735)\end{array}$ & $\begin{array}{c}-54.014 * * * \\
(7.827)\end{array}$ \\
\hline$\beta_{1}$ & $\begin{array}{c}-18.835^{* * * * *} \\
(4.998)\end{array}$ & $\begin{array}{c}-21.989^{* * * *} \\
(5.085)\end{array}$ & $\begin{array}{c}-18.330^{* * * *} \\
(5.205)\end{array}$ \\
\hline$\beta_{2}$ & $\begin{array}{c}0.470 \\
(0.499) \\
\end{array}$ & $\begin{array}{c}-0.621 \\
(0.638) \\
\end{array}$ & $\begin{array}{c}0.499 \\
(0.507) \\
\end{array}$ \\
\hline$\beta_{3}$ & & $\begin{array}{c}0.705 \\
(0.502) \\
\end{array}$ & \\
\hline Constant & $\begin{array}{l}2.198 * * * \\
(0.410)\end{array}$ & $\begin{array}{l}2.912 * * * \\
(0.484)\end{array}$ & $\begin{array}{l}2.177 * * * \\
(0.414)\end{array}$ \\
\hline Observations & 374 & 374 & 374 \\
\hline Number of country & 22 & 22 & 22 \\
\hline R-squared & 0.3745 & 0.3882 & 0.3885 \\
\hline
\end{tabular}

Note: $* * * \mathrm{p}<0.01, * * \mathrm{p}<0.05, * \mathrm{p}<0.1$.

Source: Authors' estimations.

The parameters $\beta_{1}, \beta_{2}$ and $\beta_{3}$ indicate the effect of the immigration variable of different regimes on labor costs. Parameter $\beta_{3}$ is found insignificant in the model. This clearly shows that there are no two thresholds, and that there are no three regimes in terms of the chosen variable, which is insignificant in the model. On 
the other hand, it is concluded that the inclusion or exclusion of emigration into the model does not change the effect of immigration to reduce labor costs. According to the results, in the first regime below the threshold value of immigration, $1 \%$ increase in immigration reduces labor costs by approximately $18.8 \%$, whereas immigration's effect on labor costs is statistically insignificant if immigration goes above the threshold value. Similarly, a $1 \%$ increase in unemployment rates reduces labor costs by $0.57 \%$, while a $1 \%$ increase in total factor productivity reduces labor costs by $53.8 \%$. Exports have a similar effect on labor costs. $1 \%$ increase in exports reduces labor costs by $0.41 \%$. On the other hand, imports have an adverse effect on labor costs. $1 \%$ increase in imports increases labor costs by $0.16 \%$.

According to these results, the effect of immigration on labor costs includes a threshold value. Accordingly, while there is a significant reducing effect of immigration on labor costs up to the threshold value, there is no statistically significant effect of immigration on labor costs above the threshold value. In addition, the fact that the threshold value for immigrants is at a very low level means that a limited number of immigrants have a reducing effect on labor costs for the mentioned EU countries. From this point of view, although the findings seem to support studies such as Card (2001), Borjas (2003; 2014), they support studies such as Card (1990), Friedberg and Hunt (1995) etc. above the threshold value. This situation adds originality to the study, which brings a different perspective to the relevant literature. This study shows that the effect of immigrants on labor costs varies not only in terms of periods or qualitative differences, but also depending on whether the immigrant group is above a certain threshold value. When the effect of migration on labor costs is evaluated in terms of emigration, a statistically significant effect could not be detected in contrast to Kaczmarczyk (2012), Dustmann, Frattini and Rosso (2015), Elsner (2013) etc.

\section{Conclusion}

In this paper, the effects of migration on labor costs are examined by using the nonlinear components of migration and labor costs within the framework of the structural approach. When the period under consideration is examined, it is concluded that the interaction between the countries included in the EU is quite high. It has been concluded that a mobility that occurs in labor costs, unemployment, immigrant countries or any of the emigrant countries, especially in the countries included in EU, influences other member countries of the union. The effect of migration on labor costs is revealed through the panel threshold method. Findings indicate the existence of a single-threshold model with two different 
regimes. Unlike previous studies, threshold values for immigration are determined and it is investigated whether there is a difference in the effect of immigration on labor costs above and below these thresholds. The findings are that the effect of immigration on labor costs includes a threshold value. Accordingly, while immigration has a reducing effect on labor costs up to this threshold value, there is no statistically significant effect above the threshold value. According to the results, if the inclusion of the emigration to the model is below the threshold value, the effect of immigration to reduce the labor costs is lower than if it is not included in the model. If the inclusion of emigration into the model is above the threshold value, the effect of immigration reducing the labor costs is statistically insignificant. However, contrary to some studies in the literature, a statistically significant effect of emigration on labor costs could not be determined.

In line with these results, although immigration in EU countries has a reducing effect on labor costs, this situation is sensitive to the amount of immigration and the threshold value is quite low. For this reason, the policy makers of the relevant countries should consider this value while developing policies related to migration flows and develop policies to limit the migration flows to the country above this threshold value, which will contribute to keep the balance in the local labor market dynamics. Due to the structural approach, the study generally reflects the impact of migration flows on the labor costs of EU countries. For the future studies, the researches on the qualitative differences of immigrant groups and the effects of countries' threshold value differences on labor costs will contribute to the further development of the relevant literature.

\section{References}

ANGRIST, J. A. - KUGLER, A. D. (2003): Protective or Counter-productive? Labor Market Institutions and the Effect of Immigration on EU Natives. The Economic Journal, 113, No. 488, pp. $302-331$.

AYDEMIR, A. - BORJAS, G. J. (2007): Cross-country Variation in the Impact of International Migration: Canada, Mexico, and the United States. Journal of the European Economic Association, 5 , pp. $663-708$.

BABECKÝ, J. P. - DU CAJU, T. - KOSMA, M. - LAWLESS, J. - MESSINA - RÕÕM, T. (2010): Downward Nominal and Real Wage Rigidity: Survey Evidence from European Firms. The Scandinavian Journal of Economics, 112, No. 4, pp. 884 - 910.

BARRELL, R. - FITZGERALD, J. - RILEY, J. (2010): EU Enlargement and Migration: Assessing the Macroeconomic Impacts. JCMS: Journal of Common Market Studies, 48, No. 2, pp. $373-395$.

BORJAS, G. J. (2003): The Labor Demand Curve is Downward Sloping: Reexamining the Impact of Immigration on the Labor Market. Quarterly Journal of Economics, 118, No. 4, pp. 1335 - 1374.

BORJAS, G. J. (2000): Native internal Migration and the Labor Market Impact of Immigration. Journal of Human Resources, 41, No. 2, pp. $221-258$. 
BORJAS, G. J. (2013): The Analytics of the Wage Effect of Immigration. IZA Journal of Migration, 2, No. 1, pp. 22.

BORJAS, G. J. (2014): Immigration Economics. Cambridge, MA: Harvard University Press.

BREUSCH, T. S. - PAGAN, A. R. (1980): The Lagrange Multiplier Test and Its Applications to Model Specification in Econometrics. The Review of Economic Studies, 47, No. 1, pp. $239-253$.

BRÜCKER, H. A. - HAUPTMANN, E. J. J. - UPWARD, R. (2014): Migration and Imperfect Labor Markets: Theory and Cross-country Evidence from Denmark, Germany and the UK. European Economic Review, 66, pp. 205 - 225.

CADENA, B. C. - KOVAK, B. K. (2016): Immigrants Equilibrate Local Labor Markets: Evidence from the Great Recession. American Economic Journal: Applied Economics, 8, No. 1, pp. 257 -290 .

CARD, D. (1990): The Impact of the Mariel Boatlift on the Miami Labor Market. ILR Review, 43, No. 2, pp. $245-257$.

CARD, D. (2001): Immigrant Inflows, Native Outflows, and the Local Labor Market Impacts of Higher Immigration. Journal of Labor Economics, 19, No. 1, pp. 22 - 64.

D'AMURI, F. - OTTAVIANO, G. I. P. - PERI, G. (2010): The Labor Market Impact of Immigration in Western Germany in the 1990s. European Economic Review, 54, No. 4, pp. $550-570$.

DOCQUIER, F. - OZDEN, C. - PERI, G. (2014): The Labor Market Effects of Immigration and Emigration in OECD Countries. The Economic Journal, 124, No. 579, pp. 1106 - 1145.

DURMAZ, A. - KALÇA, A. (2018): Effects of Migration Flows on Local Labor Market: A Regional Implementation on Turkey. [International Conference on Eurasian Economies.]

DUSTMANN, C. - FRATTINI, T. - PRESTON, I. P. (2013): The Effect of Immigration along the Distribution of Wages. Review of Economic Studies, 80, No. 1, pp. 145 - 173.

DUSTMANN, C. - FRATTINI, T. - ROSSO, A. (2015): The Effect of Emigration from Poland on Polish Wages. The Scandinavian Journal of Economics, 117, No. 2, pp. $522-564$.

DUSTMANN, C. - SCHÖNBERG, U. - STUHLER, J. (2016): The Impact of Immigration: Why Do Studies Reach Such Different Results? The Journal of Economic Perspectives, 30, No. 4, pp. $31-56$.

EDO, A. (2016): How Do Rigid Labor Markets Absorb Immigration? Evidence from France. IZA Journal of Migration, 5, No. 1, pp. 7.

EDO, A. (2019): The Impact of Immigration on the Labor Market. Journal of Economic Surveys, 33, No. 3, pp. $922-948$.

EDO, A. - TOUBAL, F. (2015): Selective Immigration Policies and Wages Inequality. Review of International Economics, 23, pp. $160-187$.

EDO, A. - RAPOPORT, H. (2019): Minimum Wages and the Labor Market Effects of Immigration. Labour Economics, 61, pp. 101753.

ELSNER, B. (2013): Emigration and Wages: The EU Enlargement Experiment. Journal of International Economics, 91, No. 1, pp. $154-163$.

FRIEDBERG, R. M. - HUNT, J. (1995): The Impact of Immigrants on Host Country Wages, Employment and Growth. The Journal of Economic Perspectives, 9, No. 2, pp. 23 - 44.

GERFIN, M. - KAISER, B. (2010): The Effects of Immigration on Wages: An Application of the Structural Skill-cell Approach. Swiss Journal of Economics and Statistics (SJES), 146, No. IV, pp. $709-739$.

GLITZ, A. (2012): The Labor Market Impact of Immigration: A Quasi-experiment Exploiting Immigrant Location Rules in Germany. Journal of Labor Economics, 30, No. 1, pp. 175 - 213.

GLITZ, A. (2014): The Labour Market Impact of Immigration. Els Opuscles del, CREI 36.

HANSEN, B. E. (1999): Threshold Effects in Non-dynamic Panels: Estimation, Testing, and Inference. Journal of Econometrics, 93, No. 2, pp. $345-368$.

HAZANS, M. - PHILIPS, K. (2011): The Post-enlargement Migration Experience in the Baltic Labor Markets. [IZA DP, No. 5878.] Available at: 〈http://ftp.iza.org/dp5878.pdf〉.

HOYOS, R. E. - SARAFIDIS, V. (2006): Testing for Cross-sectional Dependence in Panel-data Models. The Stata Journal, 6, No. 4, pp. $482-496$. 
HSIAO, C. (2003): Analysis of Panel Data. Second Editon. Cambridge: Cambridge University Press.

HUNT, J. (2017): The Impact of Immigration on the Educational Attainment of Natives. Journal of Human Resources, 52, No. 4, pp. $1060-1118$.

IM, K. S. - PESARAN, M. H. - SHIN, Y. (2003): Testing for Unit Roots in Heterogeneous Panels. Journal of Econometrics, 115, No. 1, pp. 53 - 74.

KACZMARCZYK, P. (2012): Labour Market Impacts of Post-accession Migration from Poland. In: OECD, Free Movement of Workers and Labour Market Adjustment: Recent Experiences from OECD Countries and the European Union.

MANACORDA, M. - MANNING, A. - WADSWORTH, J. (2012): The Impact of Immigration on the Structure of Wages: Theory and Evidence from Britain. Journal of the European Economic Association, 10, No. 1, pp. $120-151$.

MONRAS, J. (2015): Immigration and Wage Dynamics: Evidence from the Mexican Peso Crisis. [IZA Discussion Paper.] Bonn: IZA.

OTTAVIANO, G. I. P. - PERI, G. (2012): Rethinking the Effects of Immigration on Wages. Journal of the European Economic Association, 10, No. 1, pp. $152-197$.

PERI, G. - SPARBER, C. (2009): Task Specialization, Immigration, and Wages. American Economic Journal: Applied Economics, 1, No. 3, pp. 135 - 169.

PESARAN, M. H. (2004): General Diagnostic Tests for Cross Section Dependence in Panels. [IZA Discussion Papers, No. 1240.] Bonn: IZA.

PIYAPROMDEE, S. (2017): The Impact of Immigration on Wages, Internal Migration and Welfare. Technical Report. [PIER Discussion Papers.] Bangkok: PIER.

PRYYMACHENKO, Y. - FREGERT, K. - ANDERSSON, F. N. G. (2013): The Effect of Emigration on Unemployment: Evidence from the Central and Eastern European EU Member States. Economics Bulletin, 33, No. 4, pp. 2692 - 2697.

ŠKUFLIĆ, L. - VUČKOVIĆ, V. (2018): The Effect of Emigration on Unemployment Rates: The Case of EU Emigrant Countries. Economic Research - Ekonomska istraživanja, 31, No. 1, pp. $1826-1836$.

TONG, H. (1983): Threshold Models. In: Threshold Models in Non-linear Time Series Analysis, pp. 59 - 121. New York, NY: Springer.

WANG, Q. (2015): Fixed-effect Panel Threshold Model Using Stata. The Stata Journal, 15, No. 1, pp. $121-134$

ZAICEVA, A. (2014): Post-enlargement Emigration and New EU Members' Labor Markets. IZA World of Labor, 2014, pp. 40. 